\title{
INFLUENCE OF PHOSPHATE ON THE BOTANICAL COMPOSITION AND ON THE GRADE OF QUALITY OF HERBAGE ${ }^{1}$ )
}

\author{
F. SONNEVELD, A. A. KRUIJNE and D. M. DE VRIES \\ Institute for Biological and Chemical Research on Field Crops and Herbage, \\ Wageningen, The Netherlands
}

\section{SUMMARY}

A. On 115 trial fields (mainly one, but also two or three years running) the influence of phosphate application on the grade of quality of the sward was studied: a) in general (table 1), b) according to the dose applied (table 2), c) on the type of soil (table 3). The influence of phosphate application on the different agricultural groups and on some separate species was studied as well. Not only the positive or negative effect of application was established, but also the security (i.e. the difference between the number of cases with a positive or negative result, expressed in percentages of the total number of cases).

B. The indication numbers of plant species for phosphate (10), derived from the average frequencies of occurrence in the different scales of the phosphate status of old permanent grasslands, being in equilibrium (2), were compared to the reaction of separate species on phosphate application (A). Although they are not quite comparable, the results were placed next to each other in table 4 .

The conformity of the results from A and B is rather good in general. Amongst others differences were occasioned by the different methods of botanical analysis.

On trial fields the reaction on the application has been traced by means of a dry weight analysis (W-analysis). In addition the effect of the application was already judged after one or a few years, through which quickly growing and (or) superficially rooting species could take a clear lead.

The reaction of a species on the phosphate status was studied on old permanent grasslands and expressed in frequency percentages. These are not directly dependent on each other, contrary to the percentages by weight. On these grasslands slower growing and (or) deeper rooting species too have had their chance to take a place in the vegetation.

\section{INTRODUCTION}

Since the interim report on the preference of grassland species for certain plant nutrients was published in 1943 (9), investigations on this line have been continued. This was done with the aid of new research on fertilisation trial fields on the one hand, and by means of an elaborate correlative research on farm fields on the other hand. The latter $(2,8,10)$ was carried out under the direction of D. M. DE VRuEs and amongst others also a complete soil analysis of these farm fields was done. The investigations also comprised to trace what kind of influence the different fertilisations had on the grade of quality $(\mathrm{Gq})$ of the herbage on trial fields (7), and to examine the relation of the $\mathrm{Gq}$ of farm fields to manuring conditions there (8).

In this article the influence of phosphate fertilisation is first discussed. Compared to 1943 the number of trial fields has been increased from 27 to 143 . Besides this the complete data on more than a 1000 farm fields of the correlative research are at our disposal. Of these, however, the data on a large number of

1) Received for publication February 5, 1959. 
plant species concerning the rough indication of phosphate have already been published in the shape of the so called indication numbers (10).

There is an essential difference in the initial reaction of a species to a phosphate application and the difference in frequency of that species at the various phosphate conditions on old permanent grassland, the vegetation of these being adapted to the circumstances. The results of this twofold research will be discussed separately, as tracing the reaction of a species on a phosphate application constitutes the ordinary observation on short-term trial fields, the herbage receiving a sudden impulse. Of course amongst the more phosphate needing species present, the ones rooting superficially as well as those growing quickly, will profit first. They will take an, at least temporary, lead of the other species. A botanical analysis done shortly after the fertilisation will consequently show a clear positive effect on the species in question. With continuing fertilisation, a new balance will be brought into existence in the course of time on a higher phosphate level. The deeper rooting species and those with a slower development as well as the immigrated ones amongst the phoshate-loving species will have had time to profit fully from the increased soil fertility and have possibly even outstripped those which profited first. Such a long-term trial field more or less resembles an old permanent grassland. Here fluctuations in the mass ratio of species only occur under the influence of seasonal and weather conditions.

Furthermore the method of research applied is of importance to the final conclusion concerning the influence of phosphate. With trial field research the herbage is analysed according to the dry weight analysis ( $\mathrm{W}$-analysis). This is done to be able to form an accurate idea on alterations in the mass ratio of species resulting from the fertilisation. The total percentage with this method should always amount to a 100, accordingly an increase in the percentage of one species implies a decrease in the percentage of one or more of the other species. Species increasing as a result of phosphate appliction - in fact indicating a positive reaction to such applications - may show a decreasing $W \%$, if their increase is outstripped by the average of the herbage. The specific frequency method (4) according to which the more stable farm fields are analysed, gives percentages which are not directly dependent on each other and which fluctuate less in the course of time. Expansion of a species - in this case a larger spreading density - can be recorded without being influenced by the percentages of other species. The fact whether the herbage is in balance or not, as discussed above, as well as the different method of research are the reason of some contradictory effects of phosphate on the botanical composition, especially with the separate species.

The effect of a certain application of fertiliser will be fullest on soils in which the nutrient concerned is at the minimum. Consequently, in preparing fertilisation trial fields such soils are usually taken, as the effect of the kind of the amount of fertiliser concerned can be determined most accurately on these. The fertiliser is added in increasing amounts to a basic application, and generally the same objects can be found in duplicate or in triplicate in the trial field design.

The various species differ in fertiliser requirement to reach a maximal competitive ability. Generally these differences cause the shifts in the composition of the herbage with varying fertilisation. Experience has taught - some 
exceptions excluded - that the good species of grassland are more exacting about fertilisation conditions to reach a maximal competitive ability than the moderate and the inferior species. Consequently, application of increasing amounts of fertiliser will cause a shift in the competitive ability of species, and a change in the composition of the herbage will occur. This is caused by the fact that the optimum condition of good species is approached and the optimum condition of species less desirable is surpassed. To reach this effect at short term, however, the better species should already be present in the herbage. They will then be able to profit immediately from the application of fertiliser. On certain fields of very inferior botanical composition, however, they do not occur. An important qualitative effect is not to be expected in this case. A distinct improvement can be reached in a short time with superficial tillage, e.g. with a disc-harrow and with the re-seeding of good species.

The P-citric acid-number was used as a basis for indicating the phosphate status of farm fields. In this way the following classification was made:

$\begin{array}{cl}\text { P-citr } & \text { class } \\ 0-20 & \text { I } \\ 21-32 & \text { II } \\ 33-50 & \text { III } \\ 51-80 & \text { IV } \\ >80 & \text { V }\end{array}$

For phosphate trial fields only the number of $\mathrm{kg}_{2} \mathrm{O}_{5}$ per ha applied in one kind of fertiliser or another is indicated.

\section{A RESULTS OF THE RESEARCH ON FERTILISATION TRIAL FIELDS}

A number of these trial fields, principally laid out by the State Agricultural Advisers or Institutes, have been botanically analysed in the course of years. Of these short-term trial fields - mostly annual - 143 were included in a combined procedure. In this way an insight was gained into the influence of phosphate fertilisation on the entire herbage, expressed in the grade of quality. Also a clear view was obtained as to the behaviour of the most important plant species and agricultural groups of plant species separately.

On the whole such combined procedures of a number of trial fields only give few common results considered to be of more general value. This is because the starting conditions, the project of the trial and the treatment, differ from field to field.

I INFLUENCE OF PHOSPHATE FERTILISATION ON THE GRADE OF QUALITY

\section{a Influence of phosphate fertilisation in general}

As a basis for comparison the grade of quality of the 0-objects was taken, classified as follows : $0.0-4.0 ; 4.1-5.0 ; 5.1-6.0 ; 6.1-7.0 ; 7.1-8.0$ and $>8.0$. For each of these classes the average $\mathrm{Gq}$ of the fertilised objects was calculated. Not in all cases an improvement was observed. Consequently, it cannot be said in advance if the effect will be favourable. The difference between the number of cases with a positive or a negative result, expressed in percentages of the total number of cases, could serve as the "security". The result can be found in table 1 . 
Table 1 Average increase in the grade of quality $(\mathrm{Gq})$ of herbage with increasing Gqclasses by phosphate application in general. The number of cases in brackets.

\begin{tabular}{c|c|c}
\hline Gq-class & Increase of $\mathrm{Gq}$ & Security in pct \\
\hline $0.0-4.0$ & $0.83(11)$ & 46 \\
$4.1-5.0$ & $0.58(20)$ & 75 \\
$5.1-6.0$ & $0.38(34)$ & 71 \\
$6.1-7.0$ & $0.39(43)$ & 51 \\
$7.1-8.0$ & $0.11(16)$ & 13 \\
$>8.0$ & $0.05(19)$ & 21 \\
\hline
\end{tabular}

Apparently the observed Gq-increase becomes less according to a higher starting Gq. This seems to be acceptable as it could be assumed that the phosphate supply of the higher Gq-classes left nothing or little to be desired. The "security", however, in the lowest Gq-class is distinctly lower than in the next two. A suggestion was offered in the introduction, which might explain the reason why in a relatively large number of cases phosphate fertilisation does not improve poor grasslands : in a number of cases good and moderate species are absent, and consequently prevent any spreading possibility of these. Continuation of the trials would certainly have brought "security" on a higher level.

\section{$b$ Influence of the amount of phosphate fertiliser}

In answer to the question whether there is any connection between the applied amount of $\mathrm{P}_{2} \mathrm{O}_{5}$ and the grade of quality of the herbage, the following method was used. The increase of the $\mathrm{Gq}$ was determined, in comparison to that of the 0 -objects, for 9 increasing amounts of phosphate application in $3 \mathrm{Gq}$-classes. The result is to be found in table 2 .

Table 2 Average increase in the grade of quality $(\mathrm{Gq})$ of herbage with increasing doses of phosphate fertilisation. The number of cases in brackets.

\begin{tabular}{|c|c|c|c|c|c|c|c|c|c|}
\hline $\mathrm{kg} / \mathrm{ha} \mathrm{P}_{2} \mathrm{O}_{5}$ & 20 & 40 & 50 & 80 & 90 & 100 & 120 & 140 & 160 \\
\hline $\begin{array}{c}<5.51 \\
5.51-7.00 \\
>7.00\end{array}$ & $\begin{array}{l}0.52(6) \\
0.21(13) \\
0.18(4)\end{array}$ & $\begin{array}{l}0.22(12) \\
0.31(8) \\
0.01(11)\end{array}$ & $\begin{array}{l}0.77(13) \\
0.17(17) \\
0.12(11)\end{array}$ & $\begin{array}{l}0.83(17) \\
0.58(14) \\
0.54(17)\end{array}$ & $\begin{array}{l}0.26(7) \\
0.17(12) \\
0.12(5)\end{array}$ & $\begin{array}{r}0.67(8) \\
0.52(7) \\
-0.01(2)\end{array}$ & $\begin{array}{r}0.42(14) \\
0.32(9) \\
-0.16(9)\end{array}$ & $\begin{array}{l}0.42(10) \\
0.32(13) \\
0.13(7)\end{array}$ & $\begin{array}{l}1.11(7) \\
0.87(10) \\
0.17(6)\end{array}$ \\
\hline 'otal & $0.28(23)$ & $0.17(31)$ & 0.30 & $0.62(48)$ & $0.18(24)$ & $0.41(17)$ & $0.24(32)$ & $0.31(30)$ & $0.76(23)$ \\
\hline ecurity in pct & 39 & 49 & 46 & 52 & 54 & 71 & 47 & 53 & 57 \\
\hline
\end{tabular}

Apparently an increasing dose of phosphate application does not imply a proportional increase in the Gq. Despite the rather large number of cases there is little if any relation to be found in these data (compare 80 and $90 \mathrm{~kg} / \mathrm{ha}$ ). In general, however, it can be stated that the lightest applications are the most economic for a qualitative improvement of the herbage. VAN DER PAAUW (5) determined the yields of a large number of phosphate trial field and he found that the smallest application $\left(20 \mathrm{~kg} / \mathrm{ha} \mathrm{P}_{2} \mathrm{O}_{5}\right)$ gave a distinctly increased yield in 
comparison with the 0-object. More heavy applications on the other hand had an additional effect, which was not proportional to the amounts applied. With regard to the yield and the grade of quality of the harvested product, the results consequently run almost parallel.

\section{c Effect of phosphate application on different soils}

The distributing of trial fields on the different soil types allowed an extensive comparison with regard to this. The results can be found in table 3 . Here the increase of the $\mathrm{Ga}$ in comparison with the 0-object is stated under the different soils.

Table 3 Average increase in the grade of quality $(\mathrm{Gq})$ of the herbage by phosphate application on different soils. The number of cases in brackets.

\begin{tabular}{|c|c|c|c|c|c|c|}
\hline Gq-class & Sand & Sandy clay & Clay & Sticky clay & Peaty clay & Peat \\
\hline $\begin{array}{c}<5.51 \\
5.51-7.00 \\
>7.00\end{array}$ & $\begin{array}{l}0.43(5) \\
0.19(10) \\
0.06(15)\end{array}$ & $\begin{array}{c}0.79(5) \\
0.20(4) \\
-\end{array}$ & $\begin{array}{r}0.67(15) \\
0.47(26) \\
-0.07(8)\end{array}$ & $\begin{array}{c}0.16(9) \\
0.09(3) \\
-\end{array}$ & $\begin{array}{l}0.78(7) \\
0.22(5) \\
0.22(6)\end{array}$ & $\begin{array}{l}0.58(7) \\
0.80(4) \\
0.18(5)\end{array}$ \\
\hline $\begin{array}{l}\text { Total ...... } \\
\text { Security in } \\
\text { pet ..... }\end{array}$ & $\begin{array}{c}0.17(30) \\
33\end{array}$ & $\begin{array}{c}0.53(9) \\
83\end{array}$ & $\begin{array}{c}0.47(49) \\
53\end{array}$ & $\begin{array}{c}0.14(12) \\
17\end{array}$ & $\begin{array}{c}0.44(18) \\
72\end{array}$ & $\begin{array}{c}0.50(16) \\
44\end{array}$ \\
\hline
\end{tabular}

There appeared to be an extensive "security" of a fair improvement on sandy clay, clay, peaty clay and peat. In general the increase of the $\mathrm{Gq}$ as well as of the "security" was larger according to a decreasing quality of the grassland. The "security" on sandy clay and peaty clay in the class $<5.51$ amounted to $100 \%$. More or less against expectation, the number of cases in which phosphate application on inferior grasslands gives no appreciable improvement is relatively large. This has already been stated earlier. Now it appears that this only happens to be so on peat soils, the "security" in class $<5.51$ amounting to $29 \%$. On sand and especially on sticky clay the rough results are less favourable. The latter soil can be found on the drying-in soils at the border of the Noordoostpolder. The improvement as well as the "security" are distinctly lower than with the above mentioned soil types. The deficiency of moisture, characteristic of these soils in dry periods, will certainly be a large restrictive factor to the spreading of better species.

II INFLUENCE OF PHOSPHATE FERTILISATION ON THE AGRICULTURAL GROUPS OF SPECIES AND ON THE SEPARATE SPECIES

The results of this research can be looked upon as a partial extension and supplement to the publication on the preference of grassland species for certain nutrients, mentioned before (9).

Here the influence of phosphate fertilisation is studied in general as well, in the same way as this was done to judge the influence of phosphate fertilisation on the grade of quality. Also the reaction on certain circumstances of a few groups of species and separate species is traced. On the whole the reaction of good species will run more or less parallel to that of the Gq already discussed, 
the latter being determined for the greater part by the small group of good species and in particular by the species with the highest valuation number Lolium perenne.

a Influence of phosphate fertilisation on the groups of species

Phosphate fertilisation generally affects the group of good species very favourably. The reaction on various soil types did not differ much, only the reaction on sticky clay was slight. Poa pratensis was the only species which could spread here, also because it is resistant to drought. Moisture deficiency positively had a restrictive effect on the other good species.

Contrary to the good grasses the group of legumes suffered only slight changes. A distinct influence of phosphate fertilisation, however, could not be determined in any of the circumstances discussed.

The group of moderate grasses gave a completely different picture. Taken roughly this group was forced back somewhat by the fertilisation. This does not mean they are averse to phosphate fertilisation, which was proved by the increase of this group on the inferior and to a lesser extent on the moderate grasslands. On the better grasslands $(\mathrm{Gq}>6.0)$, however, its share in the herbage decreased distinctively. This behaviour could be ex-lained by the difference in need of phosphate to develop a maximal competitive ability. On inferior grasslands the optimum condition of the moderate species has not yet been reached, consequently they will be stimulated by phosphate fertilisation. On good grasslands this optimum condition has been surpassed and they will be forced back by phosphate fertilisation. Their place will be taken by the good species which approach or reach their optimal phosphate supply on these grasslands.

On sticky clay soils as well as on peaty clay, where growing conditions are not very favourable to good grasses, the moderate species will react positively.

The inferior species which comprise groups of inferior grasses, grasslike weeds and forbs were forced back by phosphate fertilisation. The need of phosphate for a maximal competitive ability of these species generally has a low level. The heterogeneousness of this group, however, allows to determine certain groups of inferior plant species, which have a distinctly different level of phosphate need.

The negative reaction on phosphate fertilisation appeared to be the strongest on insufficient grasslands, concerning especially the group of inferior plant species of the poor grasslands, e.g. the Molinieta. The inferior species of the better grasslands were forced back less distinctly, in all probability because amongst these there are species which are promoted by phosphate application e.g. such as Bromus mollis, Festuca rubra and likely also Alopecurus geniculatus, Carex hirta, Taraxacum officinale and Ranunculus repens.

On sticky clay soils a positive reaction was found. Apart from the fact that a special combination of plant species was involved here, undoubtedly the competition of good species being practically absent, played a great part too.

\section{$b$ Influence of phosphate fertilisation on a number of plant species}

The reaction of a number of species on phosphate fertilisation is indicated in 7 degrees in table 4 , i.e. 3 positive ones (the strongest reaction is -+++ ), 1 indifferent one (0), and 3 negative ones the strongest reaction is - - -).

Some short observations precede the table. 
On moderate and satisfactory grasslands Lolium perenne appears to profit only relatively little from the fertilisation, on good grasslands it is even forced back. It is promoted strongly on peat soils, but the reaction on sand soils is less favourable.

The reaction of Festuca pratensis is the strongest on sand, sandy clay and peat. It is less distinct on claylike soils.

Comparing Poa pratensis to Poa trivialis it was observed that a relatively strong reaction of the one comprised a relatively weak reaction of the other. In all probability this is influenced by weather conditions, Poa trivialis being liable to profit fully from the fertilisation in damp weather, while Poa pratensis will do so in times of drought.

In essence Poa trivialis will profit fullest from the fertilisation. It shows only slight differences on the different soils. Its reaction on sticky clay soils is unfavourable contrary to that of Poa pratensis which is still able to spread on these soils.

The behaviour of Trifolium repens runs parallel to that of the legumes, for the latter usually consist to a high percentage of this species.

Table 4 Rough reaction of some species and groups of species regarding phosphate.

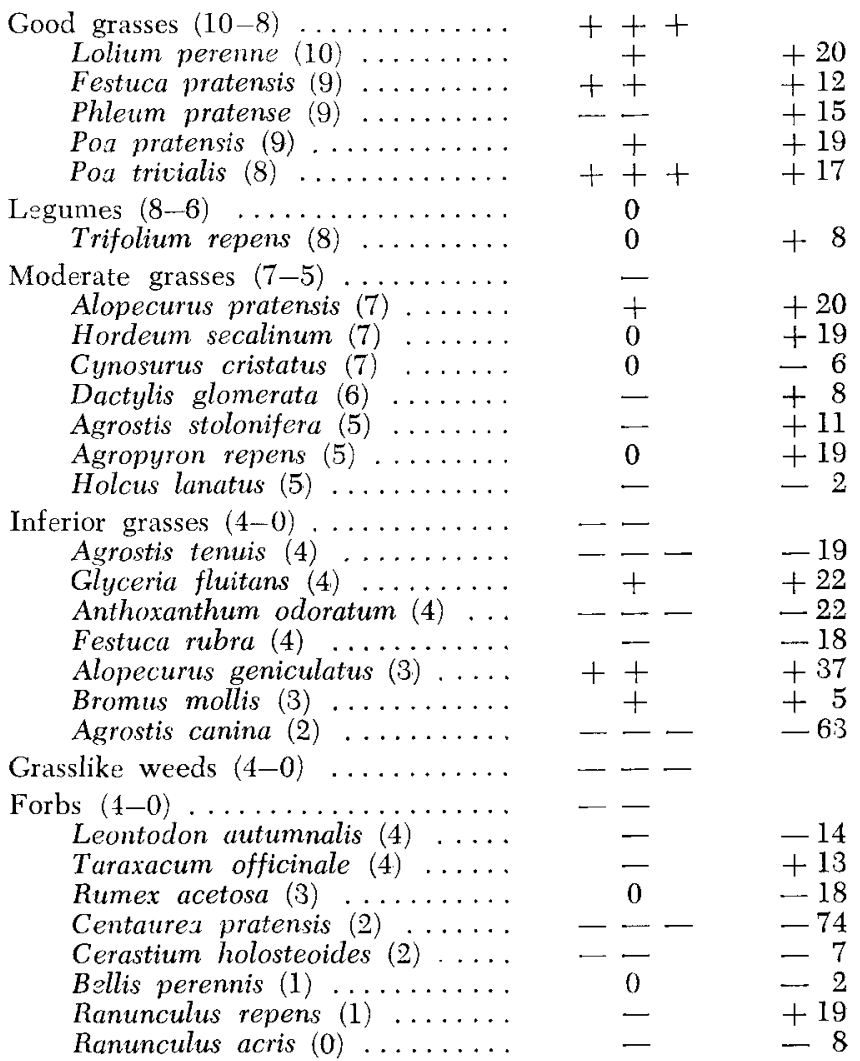

1st column: reaction on phosphate trial fields in the degrees strongly $(++++)$, moderately $(++)$, and weakly $(+)$ positive, indifferent $(0)$, weakly $(-)$, moderately $(--)$, and strongly $\left(-_{-}\right)$negative.

2nd column: phosphate indication on old permanent grasslands in the scale of +100 (absolutely loving) to -100 (absolutely avoiding).

The valuation numbers can be found in brackets behind the names of the species. 
The indication of the reaction of a few species, as can be found in the publication of De VRIES and Kruijne already mentioned (10), can be compared to the symbols found in the first column of table 4 . The data in table 4 have been provided by 115 trial fields, a considerably larger number than the 27 which have been adapted in the publication mentioned. On the whole the data agree fairly well, though now and again differences can be found. Of course the data in the first column of table 4 are slightly more reliable.

\section{B RESULTS OF THE CORRELATIVE RESEARCH ON OLD PERMANENT GRASSLANDS}

In the course of years already many results of this research have been published.

Besides tracing the relation between the phosphate status and the $\mathrm{Gq}$, the average frequency of occurrence for each plant species for the different classes of phosphate status was calculated. For a number of species this was done from 1001 fields and for some less common species from 1647 fields. These average frequency percentages per class have been expressed in percentages of the average frequency percent of all the fields (relative average frequency, $\mathrm{raF}$ ). They give a quite comparable picture concerning the reaction of species on the 5 phosphate levels (2). Later each group of 5 raF's was combined to one final number, the indication number (In), to get a rough indication on a scale from -100 to $+100(10)$.

Thus data were obtained on trial fields as well as on old permanent grasslands, indicating the reaction of a number of species and groups of species on phosphate. In table 4 these can be found next to each other. A comparison of these indications' will be given under II.

I THE PHOSPhate STATUS OF THE SOIL IN RELATION TO THE GRADE OF QUALITY OF THE HERBAGE

Previously the relation between the $\mathrm{Gq}$ and the P-citric acid-number had already been traced (8). The result was a saturation curve : up to a certain point phosphates have a marked effect upon $\mathrm{Gq}$, but beyond this limit there is no further improvement. Practically no good grasslands occur on soils with a P-citr lower than 20 and no poor ones on soils with a P-citr above 80 (8).

Average $\mathrm{Gq}$ values for the different classes of the phosphate status have been calculated as well. A calculation by means of the material, which in the mean time has been enlarged considerably, gives the following data:

$\begin{array}{lcccccc}\text { P-citr-class } \quad \ldots \ldots \ldots \ldots \ldots & 0-20 & 21-32 & 33-50 & 51-80 & >80 \\ \text { Grade of quality } \ldots \ldots \ldots \ldots & 3.8 & 5.2 & 5.9 & 6.3 & 6.5\end{array}$

These averages only expressing the rough apparent relation, hardly differ from those which have been published previously (8).

After analysis of a number of factors, it was apparent that the reaction of the sward on the phosphate status of the soil had been influenced only to a moderate degree by other factors.

However, the phosphate reaction did appear to be somewhat stronger on pure pastures (grasslands grazed only) than on alternate pastures (grasslands, alternately grazed or mown). 
An influence of the degree of humidity on the phosphate reaction was rot distinguishable.

Concerning the type of soil and the $\mathrm{pH}$, the impression was gained that the differences were relatively larger on more acid clay, peat and peaty soils. The first would be in accordance with the investigations of VAN DER PAAUW (6). He determined that, especially on clay and peat soil a certain P-citric acid would agree with a lower real fertilisation status.

\section{Phosphate status of the som In CONnection to the aVerage frequency of SEPARATE SPECIES}

The rough data indicated by the indication numbers (In's) have been listed in the second column of table 4 .

The exact interpretation of these In's, which are situated between the extremes -100 (absolutely avoiding) and +100 (absolutely loving), can be found in (10). Later on some of the numbers will be discussed in further detail.

Although some of the species form an exception, a comparison of both columns of table 4 shows that a rough parallel exists. The data should be studied with careful consideration, however, for which readers are referred to the introduction.

With a number of the most important species factor analysis was applied, just as this was done with the Gq. In this way it was possible to gain an impression on the influence of divergent factors on the effect of the phosphate status.

A high phosphate status has a positive influence on Lolium perenne $(\mathrm{In}=$ +20 ), but this influence is only very slight on wet grasslands, while on pure hayfields (grasslands only used for hay-making) and on hay pastures (one cut of hay every year and grazing afterwards) only a weak positive reaction is to be found. As already known, a high degree of humidity and the factor "haying" have a strong restrictive effect. Consequently, a high phosphate status will be especially effective, if other environmental characteristics are favourable too for this species, e.g. on pure pastures with a normal moisture content.

Festuca pratensis, reacting less distinctly than Lolium perenne on all kinds of environmental characteristics, shows a more or less stable behaviour over a large field and also with regard to the phosphate status. A distinct effect in the shape of a smaller average frequency only occurs with a low phosphate status, and even only then, where drier soils (e.g. sand and sandy clay) are concerned. The latter on themselves are already known to be less suitable for this species.

Phleum pratense also reacts somewhat less positive on the phosphate status than Lolium perenne. A weak positive relation can be found on pure pastures on humid soils and still more on soils with a normal moisture content. These are the optimal conditions for this species.

Poa trivialis, which species reacts so strongly on phosphate fertilisation (first column table 4), shows a moderate dependence on the phosphate status. This shows strongest on pure hayfields and decreases according to increased grazing. On pure pastures with a normal moisture content differences are only small. Quite possibly it experiences a heavy competition of Lolium perenne.

Trifolium repens only shows a weak relation $(\mathrm{In}=+8)$. The fact that on fields with a good phosphate status nitrogen supply is larger as well, will be 
of importance here. This condition generally is unfavourable to the development of this species. Besides it will experience a heavy competition of the productive phosphate loving grasses (1).

The weak positive relation of Agrostis stolonifera to the phosphate status appeared not to exist on the drier soils. With a high phosphate status it will be less frequent here.

Anthoxanthum odoratum roughly decreases with an increasing phosphate scatus. This, however, does not happen on pure hayfields, which is not really surprising of this hay species. Something alike happens in the case of Festuca rubra, which moreover increases somewhat on wet hay pastures according to an increasing phosphate status.

The distinct positive reaction of the little productive species Alopecurus geniculatus especially expressed itself on wet and humid hay pastures, alternate pastures and pure pastures. These usually are found on peaty soils. On pure hayfields and drier soils this species is only slightly represented.

\section{EPILOGUe}

Compilation of a large number of trial fields and farm fields, as done in the now closed research, will give many results. These must be regarded in the light of their origin. Consequently, it will remain an open question how the herbage or a plant species will react on a phosphate fertilisation in certain circumstances.

Besides all kinds of ecological factors, thought to be of importance on trial fields and farm fields, many escape our attention. This makes it difficult to gain an insight into the total complex of environmental circumstances of each field.

It was however shown distinctly that the positive reaction on a phosphate fertilisation or on a better phosphate status only reaches its maximum then, when none of the other factors can be restrictive. In other words only then, when the habitat forms an optimal condition too. From a research recently published (3) it appeared that species, known to be phosphate loving will not show this with a high phosphate supply when e.g. the potash supply is not what it should be or when the field is too wet for these species.

Only under strict reservation expectations may be expressed on the reaction on changing environmental factors of a certain species on a certain grassland. This reservation ought to be more strict according to the species having a wider ecological amplitude and it taking a more average place in its reaction.

\section{REFERENCES}

1 Bergh, J. P. VAN DEN and D. M. DE VRIES : Een bijdrage tot de oecologie van Witte klaver (Trifolium repens L.) in oud grasland. Verslag C.I.L.O. (1954) 49-55.

2 Kruijne, A. A. and D. M. DE Vhies : Gegevens betreffende belangrijke graslandplanten. Gestencilde Meded. C.I.L.O. 23 (1956), 48 pp.

$3-\ldots,--$ : Een methode tot benadering van de voornaamste milieu-eigenschappen van grasland aan de hand van de botanische samenstelling. Jaarboek I.B.S. Meded. 54 (1958) 93-98.

4 Nielen, C. Chr. J. F. and J. G. P. Dirven: De nauwkeurigheid van de plantensociologische $\frac{1 / 4}{4} \mathrm{dm}^{2}$ frequentie-methode. Versl. Landbouwk. Onderz. 56.13 (1950), $27 \mathrm{pp}$. 
5 PaAuw, F. van Der : Het nut van grondonderzoek voor de vaststelling van de fosforzuurreserve van kleigrasland en de waarde van een nieuw toegediende fosforzuurbemesting in verhouding tot die van den reeds anwezigen fosforzuurvoorraad. De Nieuwe Veldbode 46 (1939), 8 pp. (Korte Meded. Rijkslandb.proefst. Groningen, 95).

6 - - : Bemesting met fosfaat op grasland met zeer lage en met zeer hoge fosfaattoestand. Landbouwvoorl. 15 (1958) 92-96.

7 Sonnevex., $\mathrm{F}$. : Invloed van bemesting met N, P, K of Ca op de hoedanigheidsgraad van de grasmat. Verslag C.I.L.O. (1951) 29-34.

8 Vrues, D. M. DE and J. Koopmans: Het verband tussen de hoedanigheidsgraad en standplaatsfactoren. Landbouwk. Tijdschr. 61 (1949) 21-37.

9 - - and A. A. Krujjne: Over de voorkeur van graslandplanten voor bepaalde plantenvoedende stoffen. Landbouwk. Tijdschr. 55 (1943) 83-92.

$10--,--$ and $\mathrm{H}$. Moor : Veelvuldigheid van graslandplanten en hun aanwijzing van milieu-eigenschappen. Jaarboek I.B.S. Meded. 27 (1957) 183-191. 